\title{
Investigating the Link between Transit Oriented Development and Sustainable Travel Behavior in Brisbane: A Case-Control Study
}

\author{
Farjana Mostafiz Shatu ${ }^{1} \&$ Md. Kamruzzaman ${ }^{1}$ \\ ${ }^{1}$ School of Civil Engineering and the Built Environment, Queensland University of Technology, Australia \\ Correspondence: Md. Kamruzzaman, 2 George Street, Brisbane, Queensland 4000, Australia. Tel: \\ 61-7-3138-2510. E-mail: md.kamruzzaman@qut.edu.au
}

Received: June 9, 2014 Accepted: June 23, 2014 Online Published: July 2, 2014

doi:10.5539/jsd.v7n4p61 URL: http://dx.doi.org/10.5539/jsd.v7n4p61

\begin{abstract}
The purpose of this research is to empirically test the prevailing view that transit oriented development enhances the use of more sustainable modes of transport using Brisbane, Australia as a case. Transit oriented development has been adopted as a new policy tool to reduce car-based travel worldwide. Despite being a billion dollar investment, the impacts of transit oriented development on promoting sustainable travel behavior is not conclusive. The research uses a case-control approach to empirically investigate this relationship based on travel behavior data collected from 88 individuals living in two contrasting neighborhoods in Brisbane: Kelvin Grove Urban Village - a transit oriented development, and Annerley - a traditional suburb (non-transit oriented development). A comparative investigation of travel behavior was subsequently conducted using distance travelled by modes and purposes between the neighborhoods. Results show that the availability of opportunity and services located within the transit oriented development reduces the car use by $5 \%$ and increases the use of active transport by $4 \%$. The findings in this research support the implementation of TOD policies in Brisbane.
\end{abstract}

Keywords: transit oriented development, mode choice, sustainable travel behavior

\section{Introduction}

This research empirically investigates the prevailing views that transit oriented development (TOD) reduces car-based travel and enhances the use of more sustainable modes of transport (e.g. public transport, walking, and cycling) using Brisbane, Australia as a case. TODs are a relatively recent neighborhood planning/design concept (Rohe, 2009); and are characterized by: a) moderate to high residential and/or employment density; b) diverse land use patterns (e.g. mix of residential, commercial, recreational, industrial, institutional facilities); c) well connected street networks (e.g. grid or semi-grid street systems with pedestrian amenities as opposed to cul-de-sacs); and d) centered on a high frequency public transport stop/station (e.g. 400-800 meters from bus, train stations) (Cervero and Gorham, 1995; Lund, 2006; Kamruzzaman et al., 2014a). The concept of TOD has originated with other related concepts such as traditional neighborhood design, neo-traditional neighborhood design, mixed-use urban centers, transit adjacent development (TAD), and pedestrian pockets. They all perhaps represent the same neighborhood planning concept (Ryan and McNally, 1995). The underlying construct is that they all foster a compact development policy. The only difference between a TOD and the other related concepts is that a TOD is built around and within easy walking distances of a major transit stop (Bertolini et al., 2009; Renne, 2009; Rohe, 2009).

Over the years, a number of neighborhood planning concepts (e.g. garden city concept, urban renewal, community action program, suburban development, planned unit development) have been practiced and progressed in different contexts. TOD is one of the most recent in this list, and has emerged not only by incorporating the beneficial elements associated with the previous concepts, but also as a response to the perceived shortcomings of others (Rohe, 2009). Such shortcomings, for example, include: the failure to promote social equity in design (e.g. different types of housing units for different groups), and the encouragement of car based trips for daily activities and thereby reduced health outcomes (e.g. childhood obesity), increased transport related social exclusion, and increased economic and environmental externalities (e.g. congestion, greenhouse gas emissions). As a result, TODs are now associated with three major movements in planning: sustainable development, smart growth, and new urbanism (Yang, 2008).

Despite the perception that TOD reduces the weaknesses associated with other neighborhood planning 
approaches, international research findings on its success is not conclusive (Howley et al., 2009). Shyr et al. (2010) have analyzed public transport usages of 71 cities worldwide where TODs have been implemented. They identified that cities with high population density, higher number of stations, lower cost of living, and lower fare in public transport services were successful. Table 1 shows the most successful and unsuccessful cities in the world. Other studies have reported the impact of TODs for a particular city. For example, Brown and Werner (2007) found that TODs increased passenger number from $50 \%$ to $68.75 \%$ in Utah. On the other hand, unsuccessful TOD cases can be found even within a highly transit oriented society like Hong Kong (Loo et al., 2010). Therefore, the success of TODs is mixed in the literature and varies between contexts.

Table 1. Successful and unsuccessful cities in the world in attracting the use of public transport after the implement of TOD (Shyr et al., 2010)

\begin{tabular}{ccccc}
\hline & Australia & Asia & Europe & America \\
\hline Successful cities & Perth & Osaka & Moscow & San Francisco \\
& Sydney & Bangkok & Lisbon & Atlanta \\
& & Guangshou & Prague & \\
\hline Unsuccessful cities & Melbourne & Nagoya & Istanbul & Los Angeles \\
& & Delhi & Madrid & Chicago \\
& & Oshanghai & & Buenos Iris \\
& Taipei & & \\
& Kaoshiung & & \\
\hline
\end{tabular}

In addition to reducing the car based travel, TODs have also been identified to have many other benefits associated with it including a better access to jobs (Cervero and Day, 2008; Olaru et al., 2011), enhanced physical activity levels due to walking and cycling (Brown and Werner, 2007), better return on property investment (Billings, 2011), and a higher level of neighborhood satisfaction of residents (Mitrany, 2005; Lund, 2006; Lovejoy et al., 2010; Brown and Werner, 2011; Kamruzzaman et al., 2014b). In contrast, TODs are also associated with a number of undesirable features of a neighborhood e.g. higher level of crime (Bowes and Ihlanfeldt., 2001; Billings et al., 2011); deterioration of livability values due to increased density (Lin and Gau, 2006); and negative effects on real estate prices (Atkinson-Palombo, 2010).

The above findings have raised questions with respect to the effectiveness of TODs in terms of their influence in using more sustainable modes of transport as well as their attractiveness as a place to live (Ryan and McNally, 1995; Couch and Karecha, 2006). Within the Australian context, where transit oriented policies are being implemented in most of the capital cities, it is, therefore, critical to understand the impacts that TODs would bring in this context before spending billions of dollars in developing TODs. As a result, the aim of this research is to investigate whether TODs enhance the use of public transport, walking and cycling in Brisbane. This paper is structured as: Section 2 reviews policy framework within which TODs are being implemented in Brisbane; the data and method used to reach the above objective are discussed in Section 3; Section 4 portrays the findings of this research. Section 5 discusses the findings in policy terms and concludes this research.

\section{Policy Reviews: TODs in Brisbane}

The adoption of TODs in Brisbane is influenced by a number of policy guidance in Queensland, Australia including the state level policy 'Toward Q2: Tomorrow's Queensland' (Queensland Government, 2008); and the regional level policy 'South East Queensland Regional Plan 2009-2031' (Queensland Government, 2009). The Queensland Government (2008) aims to develop the state as strong, green, smart, and healthy way. The government would like to reduce congestion and carbon emissions. The South East Queensland (SEQ) Regional Plan 2009-2031 provides specific policy guidelines to achieve the above goals (Queensland Government, 2009). One particular policy is to regulate development in a more compact way through TODs. The plan targets different types of transit nodes as potential sites for TODs. These nodes are classified as primary, principal regional, major regional, specialist, principal rural, and major rural depending on the types of functions and opportunities to be supported by the development. The Plan also outlines the following key principles to be applied in these TODs (Queensland Government, 2009, p.102): 
- Land use mix (diversity): Provisioning and integration of a mix of uses to create a greater variety of services catering for the diverse needs of a vibrant community. This includes an appropriate mix of commercial and retail services, jobs, community infrastructure and open space relevant to the context of the surrounding area.

- Land use density: Incorporation of higher density residential uses in transit oriented development precincts to increase vitality and provide more convenient access to services and transport. The following baseline density guidelines have been proposed:

$\circ$ activity centers: $40-120$ dwellings per hectare (net) or greater

- suburban and neighborhood locations: 30-80 dwellings per hectare (net) or greater

○ priority transit corridors: 40 dwellings per hectare (net) or greater.

- Land use intensity: Incorporation of high-employment intensities and a mix of employment opportunities.

- Design: Ensuring development features high-quality subtropical design that maximizes amenity, street activity and pedestrian connectivity.

- Transport: Creation of an increased mode share for walking, cycling and public transport by providing high levels of accessibility and public amenity within precincts and to stations and surrounding areas for cyclists and pedestrians, with priority for pedestrians.

The above built environmental indicators are, therefore, essential to identify TOD and non-TOD types of neighborhoods in Brisbane; and consequently, to investigate the differences in travel behavior of people living between these two types of areas.

\section{Data and method}

Figure 1 outlines the research methodology used to reach the objectives of this research.

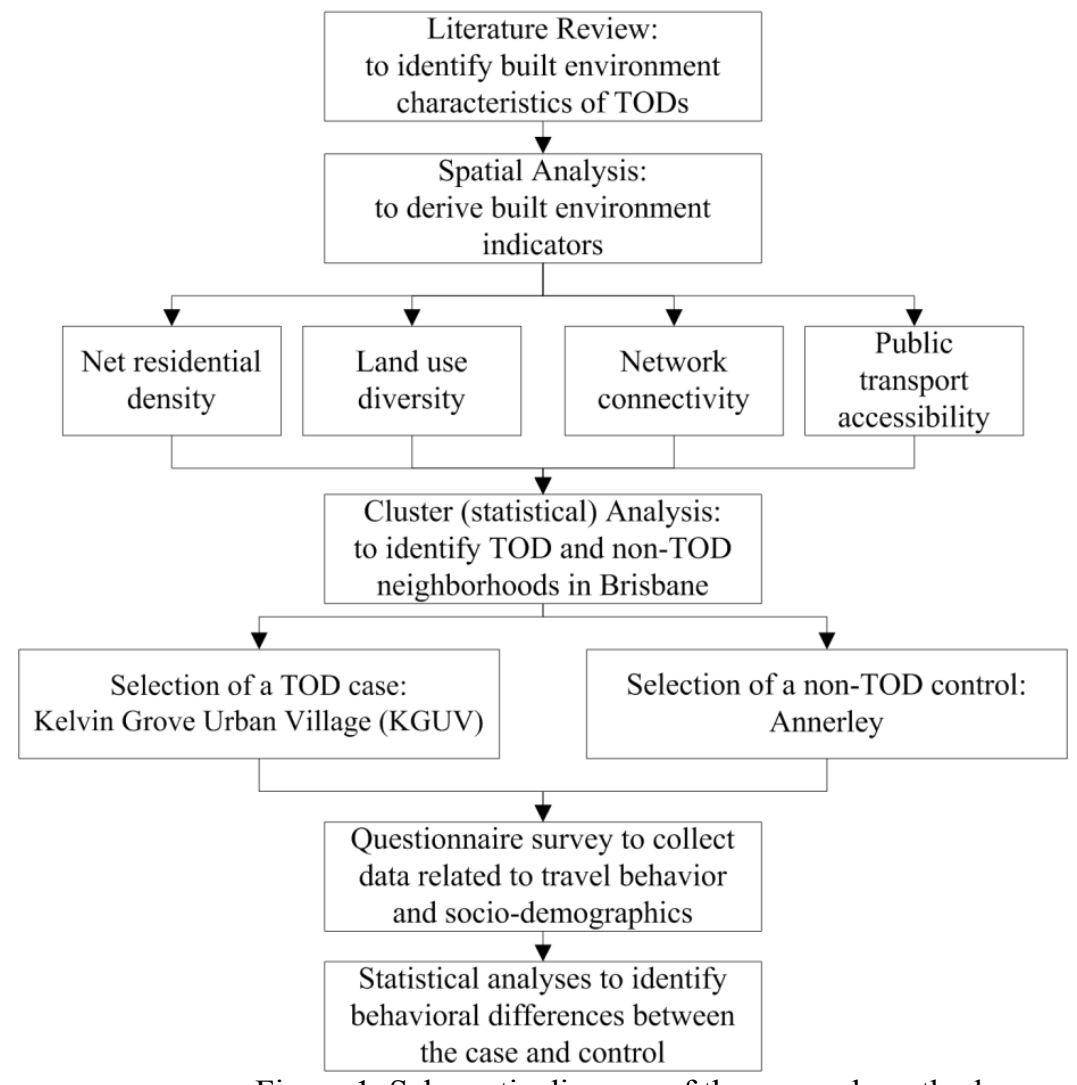

Figure 1. Schematic diagram of the research method

\subsection{Selection of Case Study Areas}

Spatial analyses were conducted to derive four built environmental indicators (e.g. net residential density, land 
use diversity, public transport accessibility, and street connectivity) for each census collection district (CCD) in Brisbane. CCDs were the smallest administrative unit used to collect census data in Australia. The derivation methods of these indicators have been discussed elsewhere, and as a result, they are not discussed here (Kamruzzaman et al., 2013). Based on these indicators, two CCDs were selected: one located in Kelvin Grove suburb and the other located in Annerley suburb (Figure 2 and 3). The selected CCD in Kelvin Grove is better known as Kelvin Grove Urban Village (KGUV) which possesses the character of a TOD whereas the selected $\mathrm{CCD}$ in Annerley is more like a conventional low-density neighborhood. For example, an independent sample $\mathrm{t}$ test results show that the net residential density of KGUV (40.11 units/hectare) is significantly higher than that of in Annerley (16.60 units/hectare). Similarly, the land use diversity of KGUV is also significantly higher (0.54) than that of in Annerley (0.01) (see also Figure 3). Figure 2 shows that both suburbs (Kelvin Grove and Annerley) are located close to the central business district (CBD) of Brisbane. On-site observation also reveals that public transport services are rarely available in the selected CCD in Annerley. Referring back to the criteria (density, land use diversity, and public transport accessibility) for a TOD as discussed in Section 1 and also policies related to TODs in Queensland (see, Section 2), KGUV clearly possesses the character of a TOD. This finding was found to be consistent with the local policy documents (Queensland Government, 2010, p.4):

"Kelvin Grove Urban Village, Brisbane - demonstrates the application of a number of transit oriented development principles. The village comprises a mix of uses, provides a high-quality public domain and access to public transport."

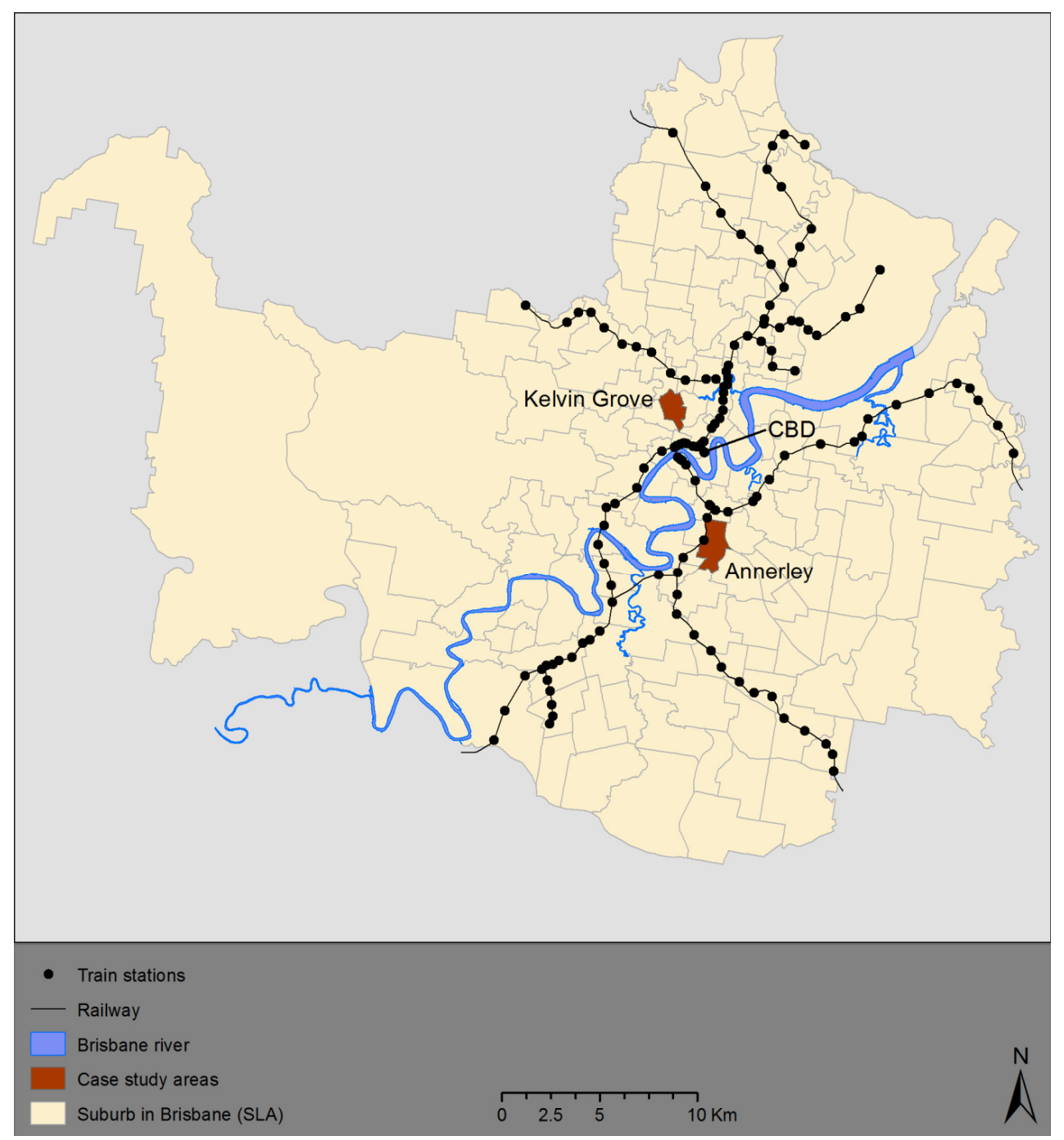

Figure 2. Location of case study areas in wider geographic context in Brisbane

Therefore, the nature of the selected case study areas provided an opportunity for a case-control study in which 
KGUV can be considered as a case whereas Annerley can be considered as a control. In a case control study, behavior of individuals who possess a specific character (e.g. living in TODs in this research - cases) is compared with a group of individuals who do not have that character (control) (Haroutune, 2009). Therefore, people living in KGUV are cases whereas people living in Annerley are control for this research. As a result, the travel behavior of people living in KGUV (case) was compared against those living in Annerley (control) in order to understand the extent to which a TOD fosters sustainable travel behavior.
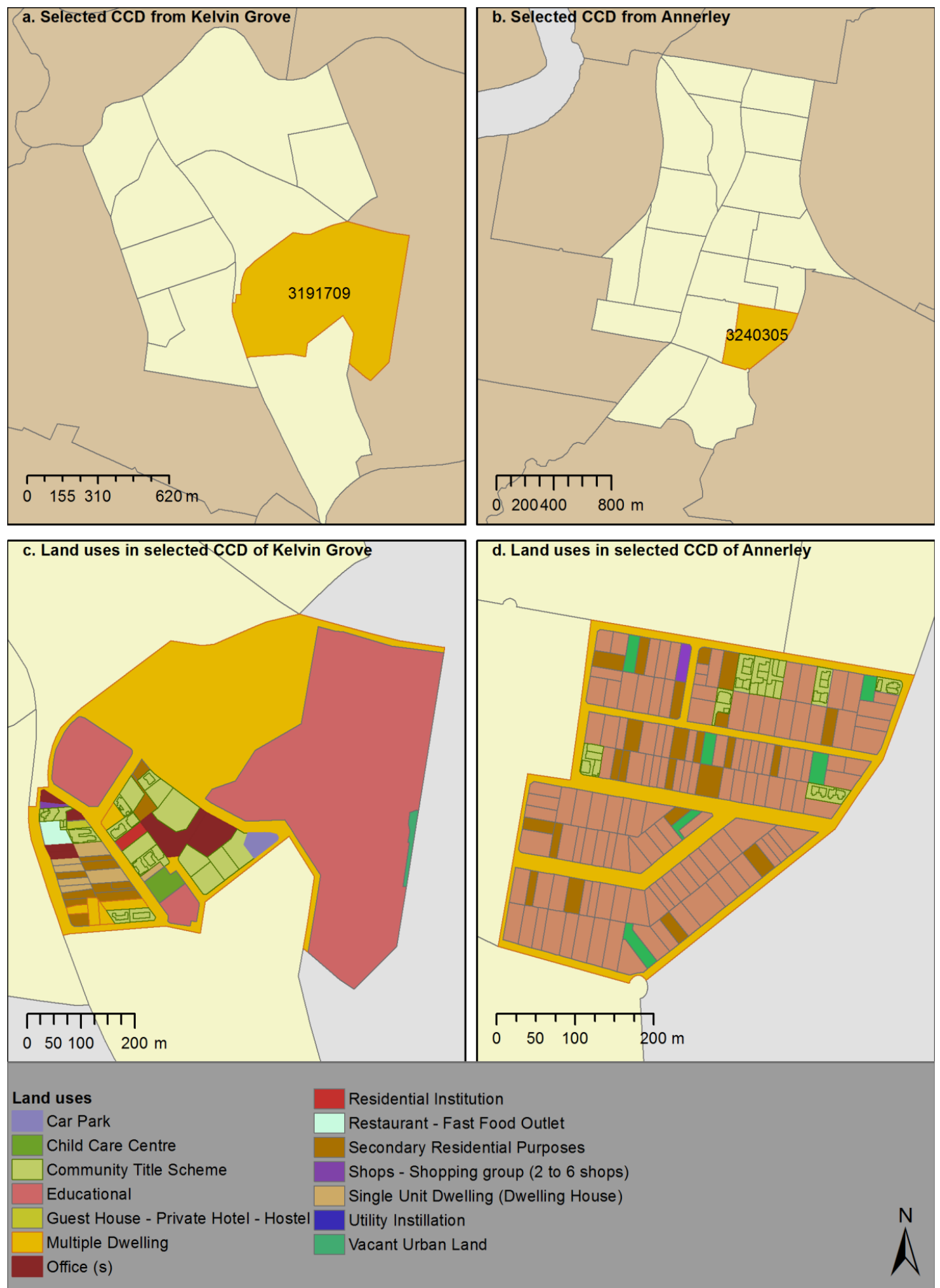

Figure 3. Land use of selected census collection districts (CCDs) in Kelvin Grove and Annerley 


\subsection{Data}

Data were collected through a questionnaire survey in this research. The survey was conducted in September 2011. Ethical clearance of the survey was obtained from the Human Research Ethics Committee at Queensland University of Technology (approval no 1100000873). The delivered to respondents and mailed back survey method was utilized to collect data. A postage paid return envelope was also provided together with the questionnaire. About 200 questionnaires were distributed to households in each case study area (total 400 in both areas) and a total of 88 questionnaires were returned (average response rate 22\%). Note that the average number of dwellings located within an urban CCD is 220 in Australia. Therefore, the sampling population included all households in the case study areas.

The questionnaire contained a total of 15 questions including 6 questions related to respondents' socio-demographic characteristics (e.g. age, gender, car-ownership, income, home ownership status, and country of birth) (Table 2). Respondents were also asked to indicated how far they travel to participate in their daily activities (e.g. work, recreation, shopping, education, and health services) and what types of transport modes (e.g. car/taxi, walk/cycle, public transport) they used in order to undertake these activities. These variables were then used to calculate a mode specific travel distances of all types of activities. Table 2 shows the socio-economic status of the respondents in each area. It illustrates that despite minor variations, the two samples are quite closely matched with respect to gender, age, home-ownership and income, and to a lesser extent with respect to occupation, and car-ownership. Therefore, it was expected that any differences in travel behavior that might exist are likely to be explained by differences in the urban form characteristics (e.g. between non-TOD and TOD). These similarities in socio-demographics and dissimilarities in TOD character support the notion of a case-control study as discussed earlier.

Table 2. Socio-demographic profile of the respondents participated in the survey

\begin{tabular}{|c|c|c|c|c|}
\hline \multirow[t]{2}{*}{ Socio-demographics } & \multicolumn{2}{|c|}{ Kelvin Grove Urban Village } & \multicolumn{2}{|c|}{ Annerley } \\
\hline & Frequency & $\%$ & Frequency & $\%$ \\
\hline \multicolumn{5}{|l|}{ Gender } \\
\hline Male & 18 & $36.7 \%$ & 18 & $46.2 \%$ \\
\hline Female & 31 & $63.3 \%$ & 21 & $53.8 \%$ \\
\hline \multicolumn{5}{|l|}{ Age group } \\
\hline Young $(<=60$ years $)$ & 37 & $75.5 \%$ & 31 & $79.5 \%$ \\
\hline Older ( $>60$ years) & 12 & $24.5 \%$ & 8 & $20.5 \%$ \\
\hline \multicolumn{5}{|l|}{ Car ownership } \\
\hline Yes & 44 & $89.8 \%$ & 36 & $92.3 \%$ \\
\hline No & 5 & $10.2 \%$ & 3 & $7.7 \%$ \\
\hline \multicolumn{5}{|l|}{ Income } \\
\hline Below $\$ 500$ per week & 9 & $20.0 \%$ & 6 & $16.2 \%$ \\
\hline$\$ 500-\$ 1000$ per week & 13 & $28.9 \%$ & 12 & $32.4 \%$ \\
\hline$\$ 1000-\$ 1500$ per week & 11 & $24.4 \%$ & 7 & $18.9 \%$ \\
\hline More than $\$ 1500$ per week & 12 & $26.7 \%$ & 12 & $32.4 \%$ \\
\hline \multicolumn{5}{|l|}{ Home ownership } \\
\hline Owner & 31 & $63.3 \%$ & 29 & $74.4 \%$ \\
\hline Rented & 18 & $36.7 \%$ & 7 & $17.9 \%$ \\
\hline Other & 0 & $.0 \%$ & 3 & $7.7 \%$ \\
\hline \multicolumn{5}{|l|}{ Country of birth } \\
\hline Australia & 37 & $75.5 \%$ & 32 & $82.1 \%$ \\
\hline Other & 12 & $24.5 \%$ & 7 & $17.9 \%$ \\
\hline $\mathrm{N}$ & 49 & & 39 & \\
\hline
\end{tabular}




\section{Results}

Table 3 shows mode specific average travel distances of people living between the areas. On average, the total distance travelled by people living in KGUV is significantly shorter $(14.57 \mathrm{~km})$ than those living in Annerley $(18.76 \mathrm{~km})$. This overall difference is, however, a result of mode specific differences. People living in Annerley travelled longer distances using the car. On average an individual travelled $11.12 \mathrm{~km}$ in a day using the car in KGUV whereas this was found to be $14.67 \mathrm{~km}$ in Annerley. Similarly, bus travelled distances were $1.59 \mathrm{~km}$ and $2.45 \mathrm{~km}$ in KGUV and Annerley respectively. These longer travel distances for people living in Annerley clearly reflect that they lack opportunities and services close by as shown in Figure 2d. Probably for this reason, people living in Annerley were reluctant to use the active transport when compared to people living in KGUV (Table 3).

Table 3. Average distance travelled by mode for different activities in a day

\begin{tabular}{lcccc}
\hline Transport mode & \multicolumn{2}{c}{ Kelvin Grove Urban Village (KGUV) } & \multicolumn{2}{c}{ Annerley } \\
\hline & Distance $(\mathrm{km})$ & \% of total distance & Distance (km) & \% of total distance \\
\hline Car (including taxi) & 11.12 & 71.41 & 14.67 & 76.39 \\
Public transport (bus and train) & 1.59 & 14.16 & 2.45 & 13.52 \\
Active transport (walking and cycling) & 1.86 & 14.42 & 1.64 & 10.09 \\
All modes & 14.57 & 100.00 & 18.76 & 100.00 \\
\hline
\end{tabular}

Table 3 also shows that the car was used to travel around $71.41 \%$ of total travel distances in Kelvin Grove whereas this was found to be significantly higher in Annerley (76.39\%). On the other hand, walking and cycling comprised of $14.42 \%$ of the total distances travelled in KGUV. This was much lower in Annerley (10\%). Surprisingly, only a little behavioral difference was found to exist in terms of public transport usage between the areas. People living in Kelvin Grove travelled $14.16 \%$ of their total distances using the public transport whereas people living in Annerley travelled $13.52 \%$ of their total distances using this mode of transport.

Table 4. Distribution of travel distances to different activities in the case study areas

\begin{tabular}{|c|c|c|c|c|c|}
\hline \multirow[t]{2}{*}{ Destinations } & \multirow[t]{2}{*}{ Distance travelled } & \multicolumn{2}{|c|}{ Kelvin Grove Urban Village } & \multicolumn{2}{|c|}{ Annerley } \\
\hline & & Frequency & Column N \% & Frequency & Column N \% \\
\hline \multirow[t]{4}{*}{ Travel distance to work } & Less than $1 \mathrm{~km}$ & 5 & $10.9 \%$ & 2 & $5.3 \%$ \\
\hline & One to two km & 9 & $19.6 \%$ & 2 & $5.3 \%$ \\
\hline & Two to five $\mathrm{km}$ & 17 & $37.0 \%$ & 8 & $21.1 \%$ \\
\hline & More than $5 \mathrm{~km}$ & 15 & $32.6 \%$ & 26 & $68.4 \%$ \\
\hline \multirow{4}{*}{$\begin{array}{c}\text { Travel distance to health } \\
\text { services }\end{array}$} & Less than $1 \mathrm{~km}$ & 6 & $12.2 \%$ & 13 & $33.3 \%$ \\
\hline & One to two $\mathrm{km}$ & 28 & $57.1 \%$ & 10 & $25.6 \%$ \\
\hline & Two to five $\mathrm{km}$ & 10 & $20.4 \%$ & 11 & $28.2 \%$ \\
\hline & More than $5 \mathrm{~km}$ & 5 & $10.2 \%$ & 5 & $12.8 \%$ \\
\hline \multirow{4}{*}{$\begin{array}{l}\text { Travel distance to } \\
\text { education }\end{array}$} & Less than $1 \mathrm{~km}$ & 13 & $36.1 \%$ & 9 & $28.1 \%$ \\
\hline & One to two $\mathrm{km}$ & 14 & $38.9 \%$ & 7 & $21.9 \%$ \\
\hline & Two to five $\mathrm{km}$ & 5 & $13.9 \%$ & 5 & $15.6 \%$ \\
\hline & More than $5 \mathrm{~km}$ & 4 & $11.1 \%$ & 11 & $34.4 \%$ \\
\hline \multirow{4}{*}{$\begin{array}{l}\text { Travel distance to } \\
\text { recreation }\end{array}$} & Less than $1 \mathrm{~km}$ & 16 & $32.7 \%$ & 12 & $32.4 \%$ \\
\hline & One to two km & 14 & $28.6 \%$ & 7 & $18.9 \%$ \\
\hline & Two to five $\mathrm{km}$ & 14 & $28.6 \%$ & 9 & $24.3 \%$ \\
\hline & More than $5 \mathrm{~km}$ & 5 & $10.2 \%$ & 9 & $24.3 \%$ \\
\hline \multirow{4}{*}{$\begin{array}{l}\text { Travel distance to food } \\
\text { shopping }\end{array}$} & Less than $1 \mathrm{~km}$ & 19 & $38.8 \%$ & 14 & $35.9 \%$ \\
\hline & One to two $\mathrm{km}$ & 23 & $46.9 \%$ & 14 & $35.9 \%$ \\
\hline & Two to five $\mathrm{km}$ & 6 & $12.2 \%$ & 11 & $28.2 \%$ \\
\hline & More than $5 \mathrm{~km}$ & 1 & $2.0 \%$ & 0 & $.0 \%$ \\
\hline
\end{tabular}


The reason for longer travel distances of people living in Annerley was further investigated in this research. Table 4 shows that most people living in Annerley made the longest distance trip for almost all purposes except food shopping. Only $33 \%$ people in KGUV travelled more than $5 \mathrm{~km}$ for work whereas this was found to be $68 \%$ in Annerley. About $11 \%$ people travelled more than $5 \mathrm{~km}$ for education in Kelvin Grove compared to $34 \%$ in Annerley. Similarly, only $10 \%$ people travelled more than $5 \mathrm{~km}$ for recreation in Kelvin Grove. This was found to be $24 \%$ in Annerley.

In contrast, most activities were undertaken within a $2 \mathrm{~km}$ distance from respondents' home location in KGUV. Table 5 shows that more than $30 \%$ individuals travelled $2 \mathrm{~km}$ or less in Kelvin Grove for the purpose of work compared to only $10 \%$ in Annerley. Despite no individual travelled more than $5 \mathrm{~km}$ for food shopping in Annerley, Table 4 shows that only $71 \%$ of them travelled $2 \mathrm{~km}$ or less for food shopping whereas this was found to be $86 \%$ in KGUV.

All these findings clearly reflect the impacts of TOD type of neighborhoods on people's activity-travel behavior in Brisbane.

\section{Discussion and Conclusion}

This research aims to investigate the impacts of TODs on travel behavior of people living in Brisbane. Two case study areas were selected to achieve the research objective. The cases were carefully selected so that they meet the requirements for a case-control study. In this research, Kelvin Grove Urban Village was used as a TOD case and Annerley as a non-TOD control. The adopted case-control study helps to disentangle the sole influence of a TOD on travel behavior. Based on the analysis provided in this research, a clear impact of TOD style neighborhood planning on sustainable mode choice behavior was identified. The results show that non-TOD type of neighborhood influences people to use the car more due to a lack of opportunities and services within the neighborhood. On the other hand, TOD style neighborhood reduces the car use. Even though some of them needed to use the car, their travel distances were shorter. Consequently, their overall levels of carbon emissions were lower - i.e. TOD contributes to environmental sustainability (Transportation Research Board, 2001; Lin and Gau, 2006; Loo et al., 2010). Moreover, TOD also influenced people to walk more and thereby enhanced physical activity level and consequently contributed to maintain good health. Such physically fitness means more economic productivity and also a reduction in medical costs (Brown and Werner, 2007).

Despite the above identified positive aspects of TODs, the influence of TOD on public transport usage is not conclusive in this research. Only a minor difference was found to exist between the areas. As a result, future research should seek to incorporate a higher number of cases and controls to robustly conclude on this topic. In addition, only descriptive statistics were provided in this research. It is not possible to conclude whether the differences reported here are significant or not. It may be possible that the differences are mainly due to socio-economic differences between the areas and not necessarily due to TOD or non-TOD character. Further analysis is required that takes into account both TOD/non-TOD character and socio-demographics of people together in investigating the differences. Despite the existence of these weaknesses, the findings reported in this research are well supported by the literature; and TOD was found to be a supportive means to promote sustainable travel behavior in Brisbane.

\section{Acknowledgments}

The authors would like to thank the students enrolled in Population and Urban Studies unit at Queensland University of Technology in 2011 for administering the surveys as a part of their class assignments.

\section{References}

Atkinson-Palombo, C. (2010). Comparing the capitalization benefits of light-rail transit and overlay zoning for single-family houses and condos by neighborhood type in metropolitan Phoenix, Arizona. Urban Studies 47(11), 2409-2426. http://dx.doi.org/10.1177/0042098009357963

Bertolini, L., Curtis, C., \& Renne, J. L. (2009). Introduction. In C. Curtis, J. L. Renne, \& L. Bertolini (Eds.), Transit Oriented Development: Making it Happen (pp. 3-12). Surrey: Ashgate Publishing Limited.

Billings, S. B. (2011). Estimating the value of a new transit option. Regional Science and Urban Economics, 41(6), 525-536. http://dx.doi.org/10.1016/j.regsciurbeco.2011.03.013

Billings, S. B., Leland, S., \& Swindell, D. (2011). The Effects of the Announcement and Opening of Light Rail Transit Stations on Neighbouhood Crime. Journal of Urban Affairs 33(5), 549-565. http://dx.doi.org/10.1111/j.1467-9906.2011.00564.x

Bowes, D. R., \& Ihlanfeldt, K. R. (2001). Identifying the impacts of rail transit stations on residential property 
values. Journal of Urban Economics 50(1), 1-25. http://dx.doi.org/10.1006/juec.2001.2214

Brown, B. B., \& Werner, C. M. (2007). A New Rail Stop: Tracking Moderate Physical Activity Bouts and Ridership. American Journal of Preventive Medicine, 33(4), 306-309. http://dx.doi.org/10.1016/j.amepre.2007.06.002

Brown, B. B., \& Werner, C. M. (2011). The residents' benefits and concerns before and after a new rail stop: Do residents get what they expect? Environment and Behavior 43(6), 789-806. http://dx.doi.org/10.1177/0013916510392030

Cervero, R., \& Day, J. (2008). Suburbanization and transit-oriented development in China. Transport Policy, 15(5), 315-323. http://dx.doi.org/10.1016/j.tranpol.2008.12.011

Cervero, R., \& Gorham, R. (1995). Commuting in transit versus automobile neighborhoods. Journal of the American Planning Association, 61(2), 210-225.

Couch, C., \& Karecha, J. (2006). Controlling urban sprawl: Some experiences from Liverpool. Cities, 23(5), 353-363. http://dx.doi.org/10.1016/j.cities.2006.05.003

Haroutune, A. (2009). The Case-Control Method Design and Applications. Oxford: Oxford University Press.

Howley, P., Scott, M., \& Redmond, D. (2009). Sustainability versus liveability: An investigation of neighbourhood satisfaction. Journal of Environmental Planning and Management, 52(6), 847-864. http://dx.doi.org/10.1080/09640560903083798

Kamruzzaman, M., Baker, D., Washington, S., \& Turrell, G. (2013, December). Residential dissonance and mode choice. Journal of Transport Geography, 33, 12-28. http://dx.doi.org/10.1016/j.jtrangeo.2013.09.004

Kamruzzaman, M., Baker, D., Washington, S., \& Turrell, G. (2014a, January). Advance transit oriented development typology: Case study in Brisbane, Australia. Journal of Transport Geography, 34, 54-70. http://dx.doi.org/10.1016/j.jtrangeo.2013.11.002

Kamruzzaman, M., Wood, L., Hine, J., Currie, G., Giles-Corti, B., \& Turrell, G. (2014b, February). Patterns of social capital associated with transit oriented development. Journal of Transport Geography, 35, 144-155. DOI: http://dx.doi.org/10.1016/j.jtrangeo.2014.02.003

Lin, J. J., \& Gau, C. C. (2006). A TOD planning model to review the regulation of allowable development densities around subway stations. Land Use Policy, 23(3), 353-360. http://dx.doi.org/10.1016/j.landusepol.2004.11.003

Loo, B. P. Y., Chen, C., \& Chan, E. T. H. (2010). Rail-based transit-oriented development: Lessons from New York City and Hong Kong. Landscape and Urban Planning, 97(3), 202-212. http://dx.doi.org/10.1016/j.landurbplan.2010.06.002

Lovejoy, K., Handy, S., \& Mokhtarian, P. (2010). Neighborhood satisfaction in suburban versus traditional environments: An evaluation of contributing characteristics in eight California neighborhoods. Landscape and Urban Planning, 97(1), 37-48. http://dx.doi.org/10.1016/j.landurbplan.2010.04.010

Lund, H. (2006). Reasons for Living in a Transit-Oriented Development, and Associated Transit Use. Journal of the American Planning Association, 72(3), 357-366. http://dx.doi.org/10.1080/01944360608976757

Mitrany, M. (2005). High density neighborhoods: Who enjoys them? GeoJournal, 64(2), 131-140. http://dx.doi.org/10.1007/s10708-005-4099-7

Olaru, D., Smith, B., \& Taplin, J. H. E. (2011). Residential location and transit-oriented development in a new rail corridor. Transportation Research Part A: Policy and Practice 45(3), 219-237. http://dx.doi.org/10.1016/j.tra.2010.12.007

Queensland Government (2010). Transit oriented development: guide to community diversity. The Department of Infrastructure and Planning, Brisbane.

Queensland Government. (2008). Toward Q2: Tomorrow's Queensland. Brisbane.

Queensland Government. (2009). South East Queensland Regional Plan 2009-2031. Queensland Department of Infrastructure and Planning, Brisbane.

Renne, J. L. (2009). From transit-adjacent to transit-oriented development. Local Environment, 14(1), 1-15. http://dx.doi.org/10.1080/13549830802522376

Rohe, W. M. (2009). From Local to Global: One Hundred Years of Neighborhood Planning. Journal of the 
American Planning Association, 75(2), 209-230. http://dx.doi.org/10.1080/01944360902751077

Ryan, S., \& McNally, M. G. (1995). Accessibility of neotraditional neighborhoods: A review of design concepts, policies, and recent literature. Transportation Research Part A: Policy and Practice, 29(2), 87-105. http://dx.doi.org/10.1016/0965-8564(94)E0008-W

Shyr, O. F., Hsiao, Y.-H., \& Andersson, D. E. (2010). How to Win Passengers and Influence Motorists? Lessons Learned from a Comparative Study of Global Transit Systems. World Academy of Science, Engineering and Technology, 68(8), 1316-1322.

Transportation Research Board. (2001). Making transit work: insight from Western Europe, Canada, and the United States. Transportation Research Board Special Report 257.

Yang, Y. (2008). A Tale of Two Cities: Physical Form and Neighborhood Satisfaction in Metropolitan Portland and Charlotte. Journal of the American Planning Association, 74(3), 307. http://dx.doi.org/10.1080/01944360802215546

\section{Copyrights}

Copyright for this article is retained by the author(s), with first publication rights granted to the journal.

This is an open-access article distributed under the terms and conditions of the Creative Commons Attribution license (http://creativecommons.org/licenses/by/3.0/). 